\title{
Rice Distribution in Kenya: The Conditions of Rice Traders in the Rice Cultivation Area Around Lake Victoria
}

\author{
Yuko Yamane* \\ International Center for Agricultural Education (ICCAE), Nagoya University Furo-cho, Japan
}

Submission: January 11, 2019, Published: January 24, 2019

"Corresponding author: International Center for Agricultural Education (ICCAE), Nagoya University Furo-cho, Japan

\begin{abstract}
This study investigates rice distribution and trade in Kenya by focusing on the activities of rice traders near the town of Ahero, in the rice cultivation area around Lake Victoria in western Kenya. We conducted a survey of local traders to obtain information regarding their trading activities and relationships with local farmers and domestic and foreign merchants. The survey results indicate that many female traders of Luo origin work as rice traders and collect rice from rice cultivation areas in the Kano Plain. At least 11 small rice cultivation areas are covered under two large-scale irrigation schemes introduced in the 1970s by the Kenyan government. Farmers in these areas cultivate rice during different seasons, and traders collect rice from the areas throughout the year. In these large-scale irrigation schemes, water is rotated to every block during different periods. Several traders are based in these areas, and more than half of the traders targeted by this study collect rice throughout the year from these large-scale irrigation scheme cultivation areas. In addition, $56 \%$ of the rice traders interviewed cultivate rice by themselves and often support other rice farmers by providing a budget for rice cultivation to secure rice supply after harvesting. Most traders are based in rice mills in Ahero and stock their rice produce to secure profits. Furthermore, the owners of rice mills support rice traders by providing tools for rice transportation from farms to markets, and often support private rice traders in various ways, such as taking them to the hospital when needed. Around half of the rice traders surveyed in this study resell their rice to domestic merchants, and nearly $90 \%$ of traders resell rice to Ugandan merchants. The results also indicate that rice traders in this area contribute to rice distribution from local farms to both the domestic and foreign markets.
\end{abstract}

Keywords: Rice Cultivation; Rice Traders; Foreign merchants; Rice mills; Harvesting; African economy

Abbrevations: SSA: Sub-Saharan Africa; NCPB: National Cereals and Produce Board; NIB: National Irrigation Board; EAC: East African Community

\section{Introduction}

The African economy has been booming in recent years, thanks to rapidly increasing resources. However, agricultural trade has witnessed stagnation in exports and a sharp increase in imports [1].

Africa's biggest challenge is agriculture: $60 \%$ of the continent's population is engaged in agriculture-based industries and live in rural areas, but this does not guarantee food security for the urban population. Rice is the most rapidly growing food commodity in Sub-Saharan Africa (SSA), driven mainly by the needs associated with increasing urbanization. Nearly $40 \%$ of the rice consumed in Africa is imported [2] and amounts to about one-third of all rice traded in the world [3]. In addition, rice consumption in Africa is expected to keep increasing, because the proportion of Africans living in urban areas is projected to increase from the current $38 \%$ to $48 \%$ by 2030 [3]. Staple food prices in cities in eastern and southern Africa rose sharply between late 2007 and early 2009 , leading to a significant increase in food insecurity and hunger [4].

Correctly identifying the actual conditions of rice traders and the problems of rice distribution is necessary to assure a smooth supply of food to urban areas. Rice distribution in Kenya was previously carried out by the National Cereals and Produce Board (NCPB), which organized and controlled the distribution until the 1990s [5]. The rice market was liberalized in 1993, after which rice trading and marketing was assumed by both individual and institutional actors at free market prices, determined by supply (local and imported) and demand [5]. These actors include farmers (for paddy rice), as well as traders and brokers (for both paddy and processed rice).

In Uganda, a conventional market and a modern market, with a supermarket as a retail outlet, coexist. The conventional market is essentially a market where traditional grains, such as 
maize, are sold, while in the modern market, rice is distributed to the supermarket through agencies of large-scale agricultural enterprises [6]. In modern markets, rice is sold to consumers through merchandise brokerage, wholesale merchants, and wholesale dealers. A similar rice distribution system exists in Kenya [5], but little information is available on the Kenyan rice market, especially the local marketing system adopted by traders and brokers.

The plain that spreads along the east coast of Lake Victoria in western Kenya has several rice cultivation areas. This plain is the second largest rice production area in Kenya [7]. Since this area is located along the border with Uganda, Ugandan merchants frequently visit the region. Information regarding the distribution of rice and other agricultural products is mostly available as statistical data and reports on the amount of imports and exports at the state level, but the identification of crop production and related problems is carried out at the national level. The actual state of the distribution of agricultural products is essential from the policy perspective, but very little information is available on local rice transactions.

Modern markets are not developed around Ahero, and the local rice produce is likely collected from the production area by individual traders and directly sold to consumers, land wholesalers, or retailers. However, the details of these transactions are largely unknown. This study aims to provide information on the state of rice distribution from the rice production area at the border between Kenya and Uganda, where rice is produced throughout the year. We focused on the activities of rice traders and gathered information regarding their conditions by conducting interviews. The analysis aims to reveal who purchases rice from these traders, and at what value and quantity. This study clarifies the role of rice traders, connecting supply and demand in the market.

\section{Study area}

Several rice cultivation areas are distributed over the Kano Plain $\left(0^{\circ} 04^{\prime} 0.20^{\prime \prime} \mathrm{S}\right.$; $\left.34^{\circ} 48^{\prime} 35.02^{\prime \prime} \mathrm{E}\right)$ located on the eastern coast of Wyndham Bay on Lake Victoria [8]. This plain lies at an elevation of approximately $1,140 \mathrm{~m}$ and is dotted with seasonal and permanent wetlands close to the lake shore. A recent report estimated that approximately 910 ha of land in this area is available for rice cultivation [9]. Two theories exist regarding the history of rice cultivation in the Lake Victoria region: one theory suggests that rice was already being cultivated by the beginning of the 20th century [8]. According to the second theory, rice cultivation was introduced by local farmers between 1930 and 1940 [8]. However, both theories suggest that rice was cultivated before the Ahero large-scale irrigation scheme had been introduced by the government in the 1970s. Irrigated rice production flourished in the area from the 1970s, while the government created conditions for large-scale irrigated rice production with the Ahero Irrigation Scheme (about 877ha) and the West-Kano Irrigation Scheme (900ha) introduced by the National Irrigation Board (NIB). The implementation of these irrigation projects began in 1969, when land was distributed to 519 farming households (1.6ha per household).

In this plain along the Lake Victoria region of western Kenya, there are at least 11 small-scale rice cultivation areas (a total of $900 \mathrm{ha}$ ) called outgrowers. The only exceptions are the two largescale schemes introduced in the 1970 s by the Kenyan government. After 1983, rice milling machines were introduced in the area, and the share of paddy handled by private millers increased. Numerous marketing boards and cooperatives have been established to handle farm produce. The city of Ahero is in the center of these rice cultivation areas. We focus our research on the activities of rice traders who collect rice from the surrounding rice cultivation areas.

\section{Methodology}

\section{Survey of rice farmers}

To conduct this survey, 17 local residents were hired, and after three days of training, they conducted a hearing survey in the residential areas of rice farmers under four scheme, NIB, Masune, Awach and Gem-Rae. We analyzed the rice cultivation situation under each scheme by targeting farmers who cultivated rice in 2011. About 331 responses were collected for each scheme. Valid respondents comprised 77 households for the NIB scheme, 78 households for the Masune scheme, 77 households for the Awach scheme, and 81 households for the Gem-Rae scheme. Then, we compared the information on rice sales with the results of the Awach and NIB schemes.

\section{Survey of rice traders and brokers}

Table 1: Affiliation of the rice traders targeted by the survey.

\begin{tabular}{|c|c|c|c|c|}
\hline S. No. & $\begin{array}{c}\text { Name of the Rice Mill } \\
\text { Used as a Base/Types of } \\
\text { Traders }\end{array}$ & Scale of Rice Mills & People & (\%) \\
\hline 1 & Kanyanga & Large Scale & 10 & 16 \\
\hline 2 & Nyando Millers & Large Scale & 10 & 13 \\
\hline 3 & Asilla & Large Scale & 8 & 8 \\
\hline 4 & Ka Wuou Miller & Small Scale & 5 & 14 \\
\hline 5 & Komore & Small Scale & 9 & \\
\hline
\end{tabular}




\begin{tabular}{|c|c|c|c|c|}
\hline 6 & Kielezo & Small Scale & 6 & 10 \\
\hline 7 & Madiaba & Small Scale & 4 \\
\hline 8 & $\begin{array}{c}\text { Trader and Broker of } \\
\text { Uganda }\end{array}$ & & 3 & 5 \\
\hline 9 & $\begin{array}{c}\text { Irrigation Board (Dry floor) } \\
10\end{array}$ & $\begin{array}{c}\text { Government Agency } \\
\text { Irrigation Board (West }\end{array}$ & $\begin{array}{c}\text { Female Semi-Public (Large } \\
\text { Scale) }\end{array}$ & 2 \\
\hline 11 & All* & 4 & 3 \\
\hline
\end{tabular}

*They do not have a rice mill as a base and go to any rice mill.

Many rice traders conduct business on their own in specific rice mills in Ahero. Three of these are large rice mills capable of milling nearly $10,000 \mathrm{~kg}$ (100 kg/100 bags) per day. Others are small mills with a processing capacity of about 20 bags per day. In a large mill, nearly 100 traders are registered, who form groups based on individual dealings in the milling room where they are based. On the other hand, in a small rice mill, around 15-20 traders are registered. Although there are no registration fees or obligations arising from registration, in some rice mills, the owner provides some degree of support to traders. Traders polish the rice brought in from the rice production areas for $2 \mathrm{Ksh} / \mathrm{kg}(1.96 \mathrm{USD} / \mathrm{kg})$ and resell polished rice in various places. The author and technician of the research station of the Ahero irrigation board interviewed rice traders based in rice mills in February 2016 and March 2017. The bases and number of traders and brokers targeted by the survey are reported in Table 1. Twenty eight out of 63 interviewees are based in large rice mills, while 20 are based in small mills. Some interviewees are not based in mills: two work as brokers and target the Ugandan market, two work at the Kenya Rice mill, two are traders based in West Kano, and another four are traders who are not based in any specific rice mill.

\section{Results and Discussion}

\section{Information about individual traders}

A total of 60 traders out of 63 declared themselves to be Luo (Table 2), while two said they were Mluya, and resided close to the border with Uganda; the ethnicity of the last interviewee is unknown. One of the Mluya traders works and lives in Ahero, is engaged in rice trade during the harvest period, when he can easily find rice, and for the rest of the year, he makes a living as a motorbike taxi driver. He carries rice to his hometown, Kakamega, located near the border between Uganda and Kenya, where he resells it.

Table 2: Traders' personal information.

\begin{tabular}{|c|c|c|c|c|c|c|c|c|c|c|c|c|c|c|}
\hline Age & People & (\%) & $\begin{array}{c}\text { Educa- } \\
\text { tional } \\
\text { Back- } \\
\text { ground }\end{array}$ & People & (\%) & $\begin{array}{l}\text { Year of } \\
\text { Expe- } \\
\text { rience }\end{array}$ & People & (\%) & $\begin{array}{l}\text { Rea- } \\
\text { son for } \\
\text { Start- } \\
\text { ing the } \\
\text { job } \\
\text { as a } \\
\text { Trader }\end{array}$ & People & (\%) & $\begin{array}{c}\text { Who } \\
\text { Taught } \\
\text { you } \\
\text { the } \\
\text { work? }\end{array}$ & People & (\%) \\
\hline $\begin{array}{c}29 \\
\text { Years } \\
\text { Old }\end{array}$ & 5 & 7.8 & $\begin{array}{c}\text { Stan- } \\
\text { dard 1-4 }\end{array}$ & 8 & 12.5 & $\begin{array}{l}\text { Half a } \\
\text { Year }\end{array}$ & 2 & 3.1 & $\begin{array}{c}\text { Invited } \\
\text { by a }\end{array}$ & 33 & 53 & $\begin{array}{c}\text { By } \\
\text { Myself }\end{array}$ & 9 & 14 \\
\hline $\begin{array}{c}30-39 \\
\text { Years } \\
\text { Old }\end{array}$ & 15 & 23.4 & $\begin{array}{c}\text { Stan- } \\
\text { dard 5-8 }\end{array}$ & 17 & 26.6 & 1 Year & 5 & 7.8 & $\begin{array}{l}\text { There } \\
\text { are }\end{array}$ & 12 & 19 & Friends & 36 & 56 \\
\hline $\begin{array}{l}40-49 \\
\text { Years } \\
\text { Old }\end{array}$ & 22 & 34.4 & $\begin{array}{c}\text { Form } \\
1-3\end{array}$ & 9 & 14.1 & 3 Year & 10 & 15.6 & $\begin{array}{l}\text { Rela- } \\
\text { tives } \\
\text { are }\end{array}$ & 8 & 13 & Family & 9 & 14 \\
\hline $\begin{array}{l}50-59 \\
\text { Years } \\
\text { Old }\end{array}$ & 14 & 21.9 & Form 4 & 23 & 35.9 & 5 Year & 14 & 21.9 & $\begin{array}{l}\text { Pat } \\
\text { Time }\end{array}$ & 3 & 5 & $\begin{array}{l}\text { Rela- } \\
\text { tives }\end{array}$ & 7 & 11 \\
\hline \multirow[t]{3}{*}{$\begin{array}{c}\text { 60-69 } \\
\text { Years } \\
\text { Old }\end{array}$} & 8 & 12.5 & College & 4 & 6.3 & 10 Year & 19 & 29.7 & & 6 & 6 & Other & 3 & 5 \\
\hline & & & No-Data & 3 & 4.7 & 15 Year & 14 & 21.9 & & & & & & \\
\hline & 64 & 100 & & 64 & 100 & & 64 & 100 & & 62 & 96.77 & & 64 & 100 \\
\hline
\end{tabular}




\section{Agricultural Research \& Technology: Open Access Journal}

\begin{tabular}{|c|c|c|c|c|c|c|c|c|c|c|c|}
\hline $\begin{array}{c}\text { Do You } \\
\text { Cultivate } \\
\text { Rice }\end{array}$ & People & (\%) & $\begin{array}{c}\text { Place of } \\
\text { Cultiva- } \\
\text { tion }\end{array}$ & People & (\%) & $\begin{array}{c}\text { Does a } \\
\text { Member } \\
\text { of }\end{array}$ & People & (\%) & $\begin{array}{c}\text { Do You } \\
\text { Have a } \\
\text { Job Other } \\
\text { than }\end{array}$ & People & (\%) \\
\hline Yes & 36 & 56 & NIB & 28 & 80 & Yes & 18 & 28.1 & Yes & 19 & 29.7 \\
\hline \multirow[t]{5}{*}{ No } & 28 & 44 & Ahero & 1 & 2.9 & No & 45 & 70.3 & No & 44 & 68.8 \\
\hline & & & Nokiso & 1 & 2.9 & Unknown & 1 & 1.6 & Unknown & 1 & 1.6 \\
\hline & & & Nyachoda & 1 & 2.9 & & & & & & \\
\hline & & & Other & 4 & 11.4 & & & & & & \\
\hline & 64 & 100 & & 35 & 100 & & 64 & 100 & & 64 & 100 \\
\hline
\end{tabular}

Most people who engage in rice trade around Ahero are Luo. In the Luo society, rice trade is thought to be a job for women, especially widows. In this study, 63 subjects were interviewed regardless of gender: 49 interviewees were female, and only 14 were male.

Most female rice traders are in their 40s, followed by women in their 30s, and, then, those in their 50s. Their educational level is relatively high: 23 traders (35.9\%) graduated from high school. If the number of high school dropouts is considered, this percentage reaches nearly $50 \%$. Four interviewees $(6.4 \%)$ graduated from college (Table 2). With respect to their experience as a trader, 19 subjects declared trading experience ranging from more than 10 years to less than 15 years, while 14 interviewees each declared experience of more than 15 years and less than 10 years, respectively. Interviewees were asked why they became rice traders and how they learned necessary job skills. More than half of the interviewees said their friends invited them to become traders (33 respondents) and taught them how to work as a rice trader (36 respondents) (Table 2 ).

More than half the respondents (36) said they cultivate rice themselves, and 28 cultivate rice under the Ahero irrigation scheme (NIB). Other traders said they cultivate rice in Nokiso, Nyachoda, and Siso, and 45 interviewees work as traders by themselves, without the help of a partner or their family. More than two thirds of respondents (44 traders out of 63) do not engage in any other business and consider rice trade their primary occupation (Table 2).

\section{Purchasing rice}

To purchase rice to trade, rice traders need to find out where rice is available around Ahero, as well as the harvesting time in the rice cultivation areas. The Ahero and West Kano irrigation schemes were both implemented in the 1970s, under which water is rotated and rice is cultivated throughout the whole year. In addition, there are at least 11 rice cultivation areas called outgrowers, where farmers irrigate by themselves.

Under the Masune scheme, where rice cultivation is carried out under rainfed conditions during the long rainy season from March to May, and harvesting is carried out in June. On the other hand, under the Awach and Gem-Rae schemes, where rice cultivation relies on irrigation canals, farmers cultivate rice in the short rainy season, from October to December. Farmers in these areas cultivate their staple food grains, such as maize and sorghum, in the long rainy season from March to May, and rice cultivation begins around July in Awach scheme. Thus, rice cultivation periods differ across schemes.

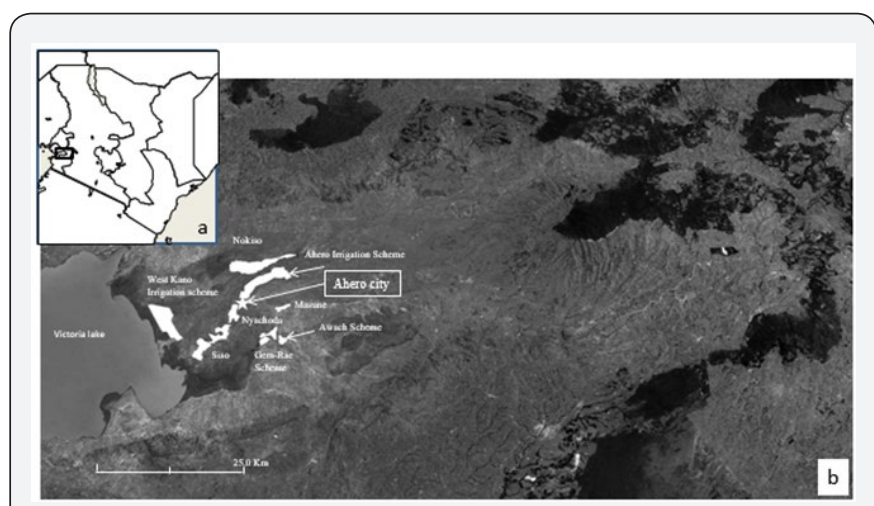

Figure 1: Location of study site in Kenya (a) and a distribution map of rice cultivation areas near the Lake Victoria (b).

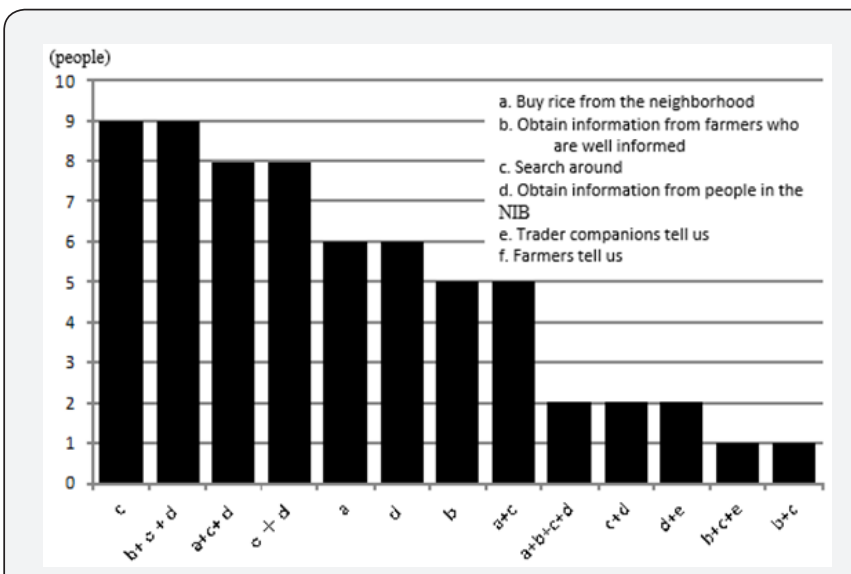

Figure 2: How do you obtain information about the rice harvesting scheme to secure rice supply?

However, in the short rainy season, the rainfall patterns are unstable, and the last term may vary significantly. Therefore, to secure rice trade, obtaining information about where and when rice is harvested is essential for traders. Interviewees were asked how they obtain information regarding where they can buy rice. Nine traders out of 64 answered that they try to collect rice on foot (Figure 1). Another nine said they use several ways to collect rice. One common way to obtain information is to rely on rice farmers 
who have been associated with these traders for many years. Alternatively, traders may try to collect rice on foot and obtain information through people associated with the NIB. Eight traders answered in a similar fashion, but said they also try to obtain rice from their neighbors (Figure 2).

Table 3: Procurement areas.

\begin{tabular}{|c|c|}
\hline Procurement place* & People \\
\hline NIB & 50 \\
\hline Nokiso & 20 \\
\hline Siso & 18 \\
\hline Awach & 4 \\
\hline Gemrae & 4 \\
\hline Nyachoda & 9 \\
\hline Masune & 1 \\
\hline Wasare & 2 \\
\hline Other & 7 \\
\hline & 115 \\
\hline
\end{tabular}

\section{*: Multiple answers}

Traders rely on multiple sources to secure rice for their trade. The average number of places each trader visits per year to purchase rice is 1.8 (Table 3). Some traders visit eight rice scheme areas in a year. Most traders (50 out of 63) purchase rice from the Ahero Irrigation scheme (Table 3). Twenty traders visit the Nokiso scheme, which is an outgrower near the Ahero irrigation scheme, to purchase rice, and 18 visits other outgrowers, such as the Siso scheme near Lake Victoria, not far from the West Kano irrigation scheme (Table 3). The Nyachoda, Awach, and Gem-Rae schemes are located far away from Ahero, but traders numbering nine, four, and four, respectively, purchase rice from these areas (Table 3). These three outgrowers are located along the main road, in relatively accessible zones. However, the rice cultivation area called was is located near Lake Victoria, and traders buy rice from outgrowers located far away from the arterial road. This suggests that traders are knowledgeable about where they can buy rice

Table 4: Procurement areas.

\begin{tabular}{|c|c|c|c|c|c|c|c|c|c|c|c|}
\hline \multicolumn{3}{|c|}{ Purchase Volume } & \multicolumn{3}{|c|}{ Purchase Price A } & \multicolumn{3}{|c|}{ Selling Price } & \multicolumn{3}{|c|}{ Gross Profit } \\
\hline Ton & People & (\%) & Ksh & People & (\%) & Ksh & People & (\%) & $10.000 \mathrm{Ksh}$ & People & (\%) \\
\hline & & & $\begin{array}{c}300 \\
\text { Million }\end{array}$ & 1 & 2 & $\begin{array}{c}400 \\
\text { Million }\end{array}$ & 1 & 2 & 50 Million & 1 & 2 \\
\hline 10000 & 1 & 2 & $\begin{array}{c}30-40 \\
\text { Million }\end{array}$ & 3 & 5 & $\begin{array}{c}40-50 \\
\text { Million }\end{array}$ & 2 & 3 & $\begin{array}{c}10-20 \\
\text { Million }\end{array}$ & 1 & 2 \\
\hline 1000 & 2 & 3 & $\begin{array}{c}20-30 \\
\text { Million }\end{array}$ & 5 & 8 & $\begin{array}{c}30-40 \\
\text { Million }\end{array}$ & 4 & 6 & 9-10 Million & 1 & 2 \\
\hline $500-900$ & 9 & 15 & $\begin{array}{c}10-20 \\
\text { Million }\end{array}$ & 11 & 18 & $\begin{array}{c}20-30 \\
\text { Million }\end{array}$ & 9 & 15 & 7-8 Million & 1 & 2 \\
\hline $100-500$ & 24 & 39 & $\begin{array}{c}5-10 \\
\text { Million }\end{array}$ & 8 & 13 & $\begin{array}{c}10-20 \\
\text { Million }\end{array}$ & 10 & 16 & 3-4 Million & 3 & 5 \\
\hline $50-90$ & 7 & 11 & $\begin{array}{l}\text { 1-5 Mil- } \\
\text { lion }\end{array}$ & 18 & 29 & $\begin{array}{c}5-10 \\
\text { Million }\end{array}$ & 8 & 13 & 2-3 Million & 7 & 11 \\
\hline Oct-50 & 9 & 15 & $\begin{array}{c}0.5-1 \\
\text { Million }\end{array}$ & 8 & 13 & $\begin{array}{l}\text { 1-5 Mil- } \\
\text { lion }\end{array}$ & 12 & 19 & 1-2 Million & 2 & 3 \\
\hline
\end{tabular}

and when, or how to obtain information about rice in these areas (Table 3).

\section{Reselling rice}

We asked traders where they resell the purchased rice. The destinations or partners to whom rice is resold are categorized into two types: domestic Kenyan merchants, who come from the neighboring cities of Kisumu, Ahero, Awsi, and Oyugisu, and Ugandan merchants, who purchase and collect rice in Ahero for their businesses. The number of transactions with local and Ugandan merchants is almost similar (20 traders and 21 traders, respectively, out of 63 ). The remaining 22 traders declared that they try reselling rice to both domestic and Ugandan merchants.

\section{Estimated transaction volume and profits for individual traders}

The gross profit (sale quantity amount - purchase amount) associated with the quantity of rice per trader was estimated by asking traders their purchase price and sale price when reselling rice. The volume of trading activity of individual rice traders around Ahero proved to be relatively large (Table 4). The average quantity of rice traded is 416 tons/year/person, and the average amount spent to purchase rice is 14.5 million Ksh/year/person. Therefore, the average value of resold rice is 16.98 millionKsh/year/person (Table 4). Traders purchase rice for an average of 4,271Ksh/bag ) and resell it for an average of 5,330Ksh/bag, which mean spent to purchase rice from the amount gained by resale, we obtain an average profit of 2.87 million Ksh/year/person. Profits close to $1,000 \mathrm{Ksh} / \mathrm{bag}$ are gained even if the milling cost of $240 \mathrm{Ksh} / \mathrm{bag}$ and transportation cost of 100-150Ksh/bag are subtracted from this amount (Table 4). An interviewed female trader of Luo origin, whose purchase of rice exceeds 300 million Ksh, engages in the rice business in cooperation with Ugandan merchants. She hires Luo people as brokers, collects rice from paddy fields in the area, ies rice in NIB's rice dryer, loads more than 100 bags of rice on a 10-ton truck, and goes back and forth between Uganda and Ahero. She said the whole process is carried out about twice a week. 
Agricultural Research \& Technology: Open Access Journal

\begin{tabular}{|c|c|c|c|c|c|c|c|c|c|c|c|}
\hline $\begin{array}{c}\text { Less than } \\
10\end{array}$ & 10 & 16 & $\begin{array}{l}0.1-0.5 \\
\text { Million }\end{array}$ & 5 & 8 & $\begin{array}{c}0.5-1 \\
\text { Million }\end{array}$ & 2 & 3 & $\begin{array}{l}\text { 0.5-1 Mil- } \\
\text { lion }\end{array}$ & 13 & 21 \\
\hline & & & $\begin{array}{l}\text { Less } \\
\text { than } 0.1 \\
\text { Million }\end{array}$ & 3 & 5 & $\begin{array}{l}0.1-0.5 \\
\text { Million }\end{array}$ & 7 & 11 & $\begin{array}{l}0.1-0.5 \\
\text { Million }\end{array}$ & 6 & 10 \\
\hline & & & & & & $\begin{array}{l}\text { Less } \\
\text { than } 0.1 \\
\text { Million }\end{array}$ & 4 & 6 & Unknown & 16 & 26 \\
\hline & & & & & & Unknown & 3 & 5 & Negetaive & 5 & 8 \\
\hline & & & & & & & & & & 6 & 10 \\
\hline & 62 & & & 62 & & & 62 & & & 62 & \\
\hline Average & 416 & & & 1452 & & & 1698 & & & 287 & \\
\hline
\end{tabular}

*: Purchase price from farmers

**: Selling price when rice is resold

***: Profit was calculated as A-B without considering any cost associated with trade

There is a significant difference in trading volume among traders: $24(62 \%)$ of the 62 traders handle 100-500 tons/year/ person for rice purchase, and nine interviewees (15\%) trade 500900 tons/year/person (Table 4). However, some trade only one tenth of the average (nine respondents trade 50-90 tons/year/ person and seven trade 10-50 tons/year/person), and significant differences existamong traders (Table 4). There are also differences in the total purchase price. Most traders (18 out of 62 ) buy 1-5 million Ksh/year/person (Table 4), eight traders purchase 0.50.1 million Ksh/year/person, and five traders buy 0.1-0.5 million Ksh/year/person. These traders purchase only one tenth or less of the average (14 million Ksh/year/person) (Table 4), while a few handle amounts 2-20 times the average: five respondents trade 20-30 million Ksh/year/person, three respondents trade 30-40 million Ksh/year/person, and one trades 300 million Ksh/year/ person. Likewise, there is a significant difference in profit: the average gross profit ranges from 0.1-0.5 million Ksh/year/person, while some traders earn less than one twentieth of the average gross profit (Table 4).

\section{Recognition and evaluation of rice variety and quality by traders}

In the rice cultivation areas of the Kano Plain, multiple varieties of rice are cultivated. The most popular variety is a high-yield variety called IR, and the second most popular variety is IITA. In addition, aromatic rice called basmati is also cultivated. We asked traders whether the price of rice depends on the variety and found that the price of aromatic Bathmati rice is higher than that of other high-yield rice varieties. The average purchase price of Bathmati is $65 \mathrm{Ksh} / \mathrm{kg}$ (according to 17 traders), while the average purchase price of IR, IITA, and BR is 36Ksh/ kg (according to 63 traders), $35 \mathrm{Ksh} / \mathrm{kg}$ (according to 30 traders), and $34.6 \mathrm{Ksh} / \mathrm{kg}$ (according to 22 traders), respectively.

In addition, we asked traders whether the destination for reselling the rice varies depending on the variety. While 22 traders out of 63 said the destination for reselling rice differs by variety,
34 traders answered to the contrary. Further, we asked the former 22 traders where IR can be resold. Nine said they resell it in the Ugandan market, four in the local market, and four in Ahero. In the case of Bathmati rice, 11 traders answered that they resell it in Mwea, in the central part of Kenya.

We also asked traders whether the quality of rice influences its price, and 46 traders out of 63 answered that the quality has a significant effect on price, while 19 traders stated that is does not. One of the traders from the latter group said that she would even mix poor-quality rice with broken rice. Further, we asked traders their criteria for distinguishing the quality of rice. Forty-four traders said they apply multiple criteria, depending on whether the rice is an aromatic variety: percentage of broken rice, color, dryness, weight, maturity, and smell. Most traders answered that rice color affects its price: the price decreases if the rice is dark.

\section{Seasonal fluctuations in rice prices}

According to the results of the survey, seasonal fluctuations in the price of rice are observed around Ahero, and 21 traders, about one third of respondents, said the market price of rice mostly increases in December (Table 5). However, 19 traders said that prices rise in April. Therefore, we concluded that the price of rice increases between the end of the year and April (Table 5). In this period, the price of rice is $45 \mathrm{Ksh} / \mathrm{kg}$ (Table 5). With respect to the reasons for the price increase, 38 traders said demand rises during the year-end and New Year holidays, such as Christmas, five traders said that prices increase because of Christmas, and nine stated that prices depend on celebrations. Therefore, a total of 52 traders answered that the holiday season induces higher demand, and the price of rice increases with demand. According to six traders, the harvest quantity of rice decreases in this period.

We also asked traders when the price of rice decreases the most. Twenty-two traders answered that price decreases are most frequent in September, followed by 12 traders who answered April. The lowest price which was answered by traders is 30 $35 \mathrm{Ksh} / \mathrm{kg}$, which is $10 \mathrm{Ksh} / \mathrm{kg}$ less than the highest price (Table 5). 
Table 5: Seasonal fluctuation of rice price as indicated by traders.

Table 5A: Highest rice price.

\begin{tabular}{|c|c|c|c|c|c|c|c|c|}
\hline \multicolumn{3}{|c|}{ When the Price of Rice is the Highest } & \multicolumn{3}{|c|}{ Highest Price } & \multicolumn{3}{|c|}{ The Reason why the Price Goes up } \\
\hline Month & People & $(\%)$ & Ksh/Kg & People & (\%) & Reason & People & (\%) \\
\hline Apr & 19 & 29.7 & 45 & 27 & 62.8 & $\begin{array}{l}\text { Demand is } \\
\text { high }\end{array}$ & 38 & 59.4 \\
\hline Dec & 21 & 32.8 & 40 & 5 & 11.6 & Christmas & 5 & 7.8 \\
\hline Dec to Mar & 6 & 9.4 & 50 & 2 & 4.7 & $\begin{array}{l}\text { Less Produc- } \\
\text { tion }\end{array}$ & 6 & 9.4 \\
\hline Dec to Apr & 3 & 4.7 & 35 & 1 & 2.3 & A Festival & 9 & 14.1 \\
\hline Nov to Dec & 4 & 6.3 & $35-40$ & 3 & 7 & Unknown & 6 & 9.375 \\
\hline Oct to Dec & 2 & 3.1 & $40-45$ & 5 & 11.6 & & & \\
\hline Jan to Apr & 2 & 3.1 & & & & & & \\
\hline Dec to May & 2 & 3.1 & & & & & & \\
\hline Oct to Jan & 1 & 1.6 & & & & & & \\
\hline \multirow[t]{2}{*}{ Unknown } & 4 & 6.3 & & & & & & \\
\hline & 64 & 100 & & 43 & 100 & & 58 & 100 \\
\hline
\end{tabular}

Table 5B: Lowest rice price.

\begin{tabular}{|c|c|c|c|c|c|}
\hline \multicolumn{3}{|c|}{ When the Price of Rice is the Lowest } & \multicolumn{3}{|c|}{ Loest Price } \\
\hline Month & People & (\%) & Ksh/Kg & People & (\%) \\
\hline Sep & 22 & 52.4 & 35 & 14 & 34.1 \\
\hline Apr & 12 & 28.6 & 33 & 13 & 31.7 \\
\hline May to Jan & 5 & 11.9 & 28 & 4 & 9.8 \\
\hline \multirow[t]{8}{*}{ Aug } & 3 & 7.1 & $28-35$ & 3 & 7.3 \\
\hline & & & 32 & 2 & 4.9 \\
\hline & & & 30 & 1 & 2.4 \\
\hline & & & 45 & 1 & 2.4 \\
\hline & & & $28-30$ & 1 & 2.4 \\
\hline & & & $30-35$ & 1 & 2.4 \\
\hline & & & $33-37$ & 1 & 2.4 \\
\hline & 42 & 100 & & 41 & 100 \\
\hline
\end{tabular}

Throughout the year, many traders in this region collect rice from multiple rice cultivation areas in the plain for resale. Therefore, they recognize the risk of purchasing rice at a high price and reselling it when the price declines, at zero profit. Traders were asked what kinds of measures they adopt to secure profits

Table 6: How do you obtain the cash necessary for rice trade?

\begin{tabular}{|c|c|c|}
\hline Methods to obtain funds for rice trade & People & (\%) \\
\hline Revolving profit by rice trade for next trade & 38 & 21 \\
\hline Being funded by Uganda merchants & 19 & 21 \\
\hline Borrow from the bank & 19 & 5.4 \\
\hline From other Businesses & 5 & 9.8 \\
\hline Other & 9 & 2.2 \\
\hline Loan & 2 & 21 \\
\hline
\end{tabular}

against market fluctuations. More than two thirds answered that they take some countermeasures. Many respondents declared that they stock their rice in stores, take measures to hedge risks, and try to anticipate fluctuations. 
To obtain profits from the difference between the purchase and resale prices of rice, traders need funding for their trade. Even though the survey results show significant differences across traders, on average, respondents said they use over 10 million Ksh a year for purchasing rice. We asked traders how they obtain funds. Many stated they rely on the profits gained from their business, while others get funds from Ugandan merchants or banks. A total of 19 respondents (one third of the interviewees) answered that they borrow money (Table 6). However, 56 traders (89\%) do not engage in any job or business other than rice trade, and only seven $(11 \%)$ have other employment activities (Table 6). More than two thirds of traders who trade with Ugandan merchants declared that they do so because Ugandan merchants buy rice at a higher price (Table 6).

\section{Relationship between traders and rice mill owners in Ahero}

Many rice traders live and stock their rice in rice mills. We asked them whether they need to polish the rice before reselling it, and 54 out of 63 responded that they do polish their rice before reselling it. There are six rice mills in Ahero, and all of them are private. Female traders often keep their rice in the rice mills, and, in many cases, resell it on the premises. Personal connections are observed between the owners of the mill and their traders.

A good rice mill guarantees security. However, one respondent said they borrow a tractor and pay afterward for being able to resell rice, "because the owner is a nice person." Others also declared a "personal connection with rice mill owners," and that the owners of some rice mills "provide cash to traders for going to the hospital."

In particular, 29 traders out of 56 answered that rice mill owners guarantee "cheaper transportation expenses," and often "provide the storage for rice." Rice traders seem to "obtain the necessary funds for rice procurement" by creating a deep connection with milling facilities.

\section{Relationship between rice traders and rice farmers}

What kinds of relationships exist between traders and farmers? Many traders are called Johahara in their local language. Although they engage in rice trade in Ahero, they live in a village with their spouses and children. Some are farmers who cultivate rice themselves (Table 7). Therefore, in addition to buying and reselling rice, in many cases, traders are familiar with farmers who cultivate rice, and some support farming activities for rice cultivation. When asked if they supported farmers in 2015, 15 respondents answered positively (Table 7). Support may take various forms: harvest costs, followed by weeding expenses, and fertilizer costs, among others. With respect to relationships between traders and farmers, our results indicate that 12 traders deal with friends, four with relatives, and six are farmers who have been trading for many years (Table 7). They all stated their intention to ensure the purchase of rice (Table 7).
Table 7: Answers for questions about the relationship between traders and rice farmers.

Table 7A: Contents of support for rice farmers by traders.

\begin{tabular}{|c|c|c|}
\hline Contents & People & (\%) \\
\hline Harvesting Fee & 9 & 33.3 \\
\hline Weeding Allowance & 7 & 25.9 \\
\hline Fertilizer Fee & 5 & 18.5 \\
\hline Tractor Cost & 2 & 7.4 \\
\hline Transplant Cost & 2 & 7.4 \\
\hline Leveling Fee & 1 & 3.7 \\
\hline Other Chemicals & 1 & 3.7 \\
\hline & 27 & 100 \\
\hline
\end{tabular}

Table 7B: Relationship with supported farmers.

\begin{tabular}{|c|c|c|}
\hline Relationship & People & (\%) \\
\hline Friend & 12 & 50 \\
\hline $\begin{array}{c}\text { Afarmer with a rela- } \\
\text { tionship for many }\end{array}$ & 6 & 25 \\
\hline Relative & 4 & 16.7 \\
\hline $\begin{array}{c}\text { Person I do not know } \\
\text { well }\end{array}$ & 1 & 4.2 \\
\hline Other & 1 & 4.2 \\
\hline Neighborhood & 0 & 0 \\
\hline & 24 & 100 \\
\hline
\end{tabular}

\section{Relationship between rice traders and Ugandan} merchants

We asked traders about their relationships with Ugandan merchants, and 43 out of 63 answered that they work with Ugandan rice merchants because they purchase rice at a higher price (38 respondents) or a certain price (33 respondents). Traders also mentioned as a reason that Ugandan merchants are partners who trade on conditions (Table 8). In some cases (10 respondents), traders provide money because the trading partners are their friends, and this means that they play the role of brokers who act as bridges between Ugandan merchants and farmers. Ugandan merchants buy rice from this area and resell it (24 respondents) in Sudan, Chad, North Uganda, Central Africa, and countries other than Uganda (Table 8).

Table 8: Reasons for trading with Ugandan merchants.

\begin{tabular}{|c|c|c|}
\hline & People & (\%) \\
\hline $\begin{array}{c}\text { They buy rice at a } \\
\text { high price }\end{array}$ & 38 & 39.6 \\
\hline $\begin{array}{c}\text { They buy at a certain } \\
\text { price }\end{array}$ & 33 & 34.4 \\
\hline They provide funds & 15 & 15.6 \\
\hline They are friends & 10 & 10.4 \\
\hline & 96 & 100 \\
\hline
\end{tabular}




\section{Summary and Conclusion}

At least 11 rice cultivation areas, covered under two largescale irrigation schemes, are distributed in the plain east of Lake Victoria in western Kenya. Rice is available throughout the year in these zones. Rice traders collect rice from these rice cultivation areas and resell it in the domestic market and to Ugandan merchants. Traders in this area are mostly of Luo origin, and many are women. Luo people use their own language in their daily lives, and it seems that Luo is more useful to communicate with local farmers and collect rice, even in rural zones. In addition, some traders cultivate rice by themselves. Therefore, they can easily find rice and sometimes provide funds to other rice farmers and help them in their cultivation. Many rice traders engage only in rice trade. The survey results suggest that traders contribute to the smooth collection of rice from the rice cultivation areas scattered in the region.

Among the Luo, rice trade is considered to be a woman's occupation. In many regions in Africa, rice is not a staple food. However, in Madagascar, where most people cultivate and consume rice, nearly $70 \%$ of rice traders are men with 7.8 years of average experience [10]. On the other hand, many traders in the target area possess more than 10 years of experience. The Madagascar rice traders often own a motorcycle and a car and collect rice on their own, while Luo rice traders often pay transportation fees and carry rice by bike or tractor from the production place. Tractors for transportation from farm to rice mill, where the trader makes their base, are usually provided by the owner of a rice mill.

The gross income obtained from trading rice varies among traders. Around one third of respondent's trade 100-500 tons per year. The average profit of a trader or broker in Mwea is 47 USD per ton [5], which means 4,700-23,500 USD per year, as the average income of rice farmers in Mwea is about 50,000Ksh/ person (48,000USD/person)) [11]. Although large variations are observed in traders' incomes, many of those who earn more than rice farmers can be inferred to be traders or brokers, who may gain extra profits by appropriating some resources. Uncoordinated marketing due to the poor organization of farms leads to market dominance by brokers and traders, thus affecting rice trade [5].

Many rice traders are based in rice mills in the city, store the rice at the rice mills, and sell it depending on opportunities, while trying to anticipate price fluctuations. Seasonal fluctuations are observed in the price of rice, and traders are aware that the price is high from October to April and low from May to September. Traders make profits by stocking rice in rice mills until the price rises. Nigerian rice traders are also based in milling facilities [12], and in different countries, the situation may be similar, in some cases.

The seasonal variation observed in Kenya is similar to that in Tanzania. From the end of May, when the long rainy season ends, until June and July, corn and rice are harvested; many products are in the market at this time, which causes the price of the crop to fall. Rice prices in all local markets in Tanzania are connected to the international rice price with a $20-40 \%$ transmission adjustment, although local prices are also influenced by the volume of the local harvest [13]. In Africa, rice is often grown as a commercial crop, and the staple food of people in this area is not rice, but maize. Rice milling is only carried out in areas where rice can be harvested, and large rice mills are based only in Ahero. Many traders register their names at their respective rice mills, take the mills as bases, or borrow the tractors from rice mills at a low price to transport rice from the production area (instead of paying the rice milling fee). In some cases, traders may personally receive support from the rice mill owner. More than half of the rice traders in the region trade with Ugandan merchants and resell rice in the Ugandan market. Some of them are brokers and are hired by Ugandan merchants to collect rice from the area. The rice from this area often crosses the border and flows to countries, such as Uganda or Sudan. Under the East African Community (EAC), tariff rates are set at 6\% except for commodities deemed as "sensitive" [6]. The EAC declared rice to be a sensitive commodity and implemented a $75 \%$ tariff on rice imported from outside the community [13]. This study is based on information obtained from traders. Therefore, we cannot determine the amount of rice that flows to Uganda, and even though some Ugandan merchants engage in trades around Ahero, it is not clear whether rice from this area reaches countries such as Sudan. However, more than half of the traders responded that Ugandan merchants collect significant amounts of rice in this area, and it is conceivable that part of this rice crosses the border and flows to Uganda. Therefore, the Kenyan government needs to focus on the distribution of local rice when launching policies primarily based on domestic food circumstances.

\section{Acknowledgement}

This study supported by Grant-in-Aid for Scientific Research C (:70528992).

\section{References}

1. Hirano K (2010) Report 3 Agriculture in Africa: Structure of the crisis Africa Academic Symposium Report 2009 Scientific Meeting: Toward the Africa's Future Agriculture and Rural Areas: Approach from the Field. African Study 76: 45-47.?

2. Saito K (2010) Contribution of crop science to rice cultivation promotion towards poverty reduction in Africa Symposium of the Japanese Crop Science Association Symposium Article Date Era 80(2): 235-244.

3. Seck PA, Tollens E, Wopereis MCS, Diagne A and Bamba I (2010) Rising trends and variability of rice prices: Threats and opportunities for subSaharan Africa. Food Policy 35(5): 403-411.

4. Nicole M, Mason TS, Chapoto JA and Donovan C (2011) Putting the $2007 / 2008$ global food crisis in longer-term perspective: Trends in staple food affordability in urban Zambia and Kenya. Food policy 36(3): 350-367

5. Chemonics International Inc. (2010) Staple Foods Value Chain Analysis: Country Report - Kenya The United States Agency for International Development (Chemonics International Inc) 234.

6. Kikuch M (2017) The establishment of rice market in Uganda and the current situation of domestic rice competitiveness. Tropical Agriculture and Development 10(2): 70-72. 
7. Onyango AO (2014) Exploring Options for improving Rice production to resource hunger and poverty in Kenya. World Environment 4(4): 172-179.

8. Niemeijer R, Marianne G, Kliest T and Ogonda JH 1985 Nutritional aspect of rice cultivation in Nyanza province, Kenya. African studies. Center, Leiden, (Netherlands), 155.

9. Romano K (2009) Food Security permanent secretary ministry of agriculture. Ministry of Agriculture. pp. 1-31.

10. Arimoto Y, Sakurai T, Tanaka M, Tsilavo R (2013) Rice trading in Madagascar: Report on Rice trader Survey 2011. PRIMCED Discussion paper series, No 38. Poverty reduction, institutions, Markets and policies in Developing countries Toward a theory of comparative economic development, Hitotubashi University.

11. Ito N (2017) Food distribution mechanism and function in rural Africa - Analysis of rice consumption process in Kenya Irrigation Project Area - Agriculture, Forestry and Fisheries Policy No. 27: 1-24.

12. Welsch D (1966) Rice Marketing in Eastern Nigeria. Food Research Institute Studies 6(3): 329-352.

13. Minot NW (2010) Staple food prices in Tanzania. AgEcon Research, p. 16.

\section{Your next submission with Juniper Publishers will reach you the below assets}

- Quality Editorial service

- Swift Peer Review

- Reprints availability

- E-prints Service

- Manuscript Podcast for convenient understanding

- Global attainment for your research

- Manuscript accessibility in different formats

( Pdf, E-pub, Full Text, Audio)

- Unceasing customer service

Track the below URL for one-step submission https://juniperpublishers.com/online-submission.php 